Jurnal Pemikiran \& Penelitian Psikologi

\title{
PSIKOLOGIA
}

p-ISSN: $185-0327$

e-ISSN: $2549-2136$

www.jurnal.usu.ac.id/psikologia

\section{PERAN EXPERIENCED STIGMA TERHADAP SELF ESTEEM PADA SUKU NIAS}

\section{ROLE OF EXPERIENCED STIGMA TO SELF ESTEEM IN \\ NIAS ETHNIC}

\author{
Lucy Gabriella Hutauruk dan Ridhoi Meilona Purba \\ Psikologia: Jurnal Pemikiran \& Penelitian Psikologi \\ Tahun 2018, Vol. 13, No. 3, hal.172-182
}

Artikel ini dapat diakses dan diunduh pada:

www.jurnal.usu.ac.id/psikologia

\section{Dipublikasikan oleh:}

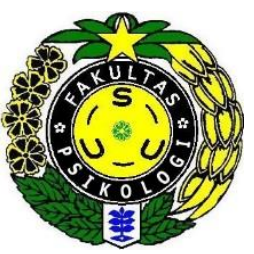

Fakultas Psikologi

Universitas Sumatera Utara

Jl. Dr. Mansyur No. 7 Medan. Telp/fax: 061-8220122

Email: psikologia@usu.ac.id 


\title{
PERAN EXPERIENCED STIGMA TERHADAP SELF ESTEEM PADA SUKU NIAS
}

\author{
Lucy Gabriella Hutauruk dan Ridhoi Meilona Purba \\ Universitas Sumatera Utara
}

\begin{abstract}
ABSTRAK
Penelitian ini bertujuan untuk mengetahui peran experienced stigma terhadap self esteem pada suku Nias. Penelitian ini melibatkan 151 orang suku Nias yang berdomisili di Medan. Pengambilan sampel dilakukan dengan incidental sampling dan diolah dengan uji regresi linier sederhana dengan bantuan SPSS 17.0 for windows. Alat ukur yang digunakan adalah skala experienced stigma dan skala self esteem yang disusun oleh peneliti. Hasil penelitian ini menunjukkan terdapat peran experienced stigma terhadap self esteem pada suku Nias $(R=0,577 ; R 2=0,333 ; p=0,000<0,05)$, peran yang diberikan experienced stigma terhadap self esteem suku Nias adalah sebesar 33,3\%. Selanjutnya, pada hasil penelitian ini didapatkan bahwa experienced stigma suku Nias berada dalam kategori yang positif, yang artinya adalah mereka tidak membentuk penilaian negatif terhadap dirinya sendiri meskipun terstigma, sehingga tidak menurunkan self esteem suku Nias yang menjadi subjek penelitian ini.
\end{abstract}

Kata kunci : Experienced Stigma, Self Esteem, Suku Nias

\section{ROLE OF EXPERIENCED STIGMA TO SELF ESTEEM IN NIAS ETHNIC}

\begin{abstract}
S
This study aims to determine the role of experienced stigma against self esteem in Nias ethnic. The study involved 151 people of Nias ethnic who lived in Medan. Sampling was done by incidental sampling and processed by simple linear regression test with an SPSS 17.0 Software Program. The instrument in this research are the scale of experienced stigma and self-esteem scale developed by the researchers. These results indicate there is the role of experienced stigma against self esteem in Nias ethnic $(R=0.577 ; R$ $2=0.333 ; p=0.000<0.05$ ), which means that the experienced stigma cast by $33.3 \%$ to self esteem in Nias ethnic. Then, result from this study find that experienced stigma in Nias ethnic is positive, which means that they don't form a negative assessment toward themself even they are stigmatized, so their self esteem do not get lowered.
\end{abstract}

Keywords : Experienced Stigma, Self Esteem, Nias Ethnic

*Korespondensi mengenai penelitian ini dapat

dilayangkan kepada: psikologia@usu..ac.id
Rekomendasi mensitasi:

Hutauruk, L.G., Purba, R.M. (2018). Peran Experienced Stigma terhadap Self-Estem pada Suku Nias. Psikologia :Jurnal Pemikiran dan Penelitian Psikologi, 13(3), 172-182 
Bhinneka Tunggal Ika adalah semboyan Indonesia yang sudah dikenal sejak dahulu, yang bermakna berbedabeda tetapi tetap satu. Ragam budaya Indonesia merupakan kekayaan unik yang tidak dimiliki setiap bangsa di dunia. Ragam ini terlihat baik dari kondisi sosial kultural dan geografisnya. Badan Pusat Statistik (BPS) sampai dengan tahun 2011 mencatat bahwa Indonesia memiliki 1.128 suku bangsa dengan lebih dari 746 bahasa daerah yang tersebar dalam 13.000 pulau dari Sabang hingga Merauke.

Salah satu Provinsi terbesar di Indonesia ialah Sumatera Utara. Menurut data dari Badan Pusat Statistik Provinsi Sumatera Utara, berdasarkan hasil sensus tahun 2010, jumlah penduduk Sumatera Utara sebesar 13,77 jiwa yang terdiri dari berbagai macam suku bangsa. Suku bangsa paling banyak di provinsi ini adalah Batak (Tapanuli/Toba, Karo, Mandailing dan Pakpak) sebesar 44,75\%, suku Jawa 33,40\% dan sisanya merupakan suku Tionghoa, Melayu, Nias dan lainlain. BPS juga melaporkan bahwa Provinsi Sumatera utara merupakan provinsi yang memiliki suku bangsa yang sangat beragam dan diakui oleh pemerintah.

Sarwono (2007) mengatakan dari keberagaman etnik-etnik yang terpisah secara geografis dan sosial budaya yang berbeda, mempunyai dan mengembangkan pengalaman psikologis masing-masing, yang pada akhirnya menghasilkan identitas etnik masingmasing juga. Keterikatan pada identitas etnik tersebut akan menimbulkan saling prasangka antar etnik yang nantinya bisa berdampak kepada proses akulturasi bangsa. Hal ini sejalan dengan pendapat Widiastuti (2013) yang mengatakan bahwa kelompok masyarakat yang beragam mempunyai potensi untuk konflik. Perbedaan yang terdapat dalam masyarakat karena nilai-nilai budaya yang dilatar belakangi sosio-kultural, akan menjadi pendorong munculnya perasaan kesukuan yang berlebihan dan dapat memicu munculnya nilai negatif berupa sikap membeda-bedakan perlakuan sesama anggota masyarakat, sehingga menimbulkan prasangka yang bersifat subjektif.

Hogg (2011) mengatakan bahwa target dari prasangka adalah kelompok yang terkena stigma dari masyarakat. Stigma dapat dikonseptualisasikan dalam hal perceived, internalized atau enacted stigma (Goffman, 1963). Pengalaman stigma juga dapat dideskripsikan sebagai "persepsi" atau keyakinan akan adanya sikap atau perilaku stigma dalam masyarakat, atau sebagai sebuah proses "internalisasi", dimana pikiran atau perasaan negatif muncul pada individu terstigma (Luoma et al, 2007). Dalam hal ini, Mickelson mengistilahkannya dengan perceived stigma, yaitu perasaan negatif individu terhadap dirinya sendiri karena stigma yang dimilikinya (internalized stigma) dan persepsi individu tersebut mengenai bagaimana perilaku atau perasaan orang lain terhadap kondisi stigma yang dimilikinya (experienced stigma).

Donaldson (2015) mengatakan bahwa individu yang terkena stigma bisa jadi mempunyai keyakinan tersendiri mengenai bagaimana penilaian atau perasaan orang lain terhadap kondisi stigma yang ada pada dirinya dan kemudian menginternalisasi penilaian tersebut. Keyakinan personal tersebut semakin jelas setelah mereka memperoleh 'label' dari kondisi stigma yang 
diterimanya (Link, 1987). Sehingga, dapat dikatakan bahwa, ketika seseorang menerima suatu perlakuan atau penilaian negatif dari lingkungan (terstigmatisasi), kemudian membentuk suatu keyakinan atau pesepsi tersendiri akan hal tersebut (experienced stigma) dan akhirnya membentuk evaluasi negatif terhadap dirinya sendiri karena stigmatisasi tersebut.

Mickelson dan William (2008)

mengatakan bahwa orang yang terstigma cenderung untuk menginternalisasi penilaian-penilaian negatif dari lingkungannya dan membentuk evaluasi diri yang negatif pula mengenai dirinya atau memiliki self esteem yang rendah. Hal ini sejalan dengan pendapat Hogg (2011) yang mengatakan bahwa kelompok yang terkena stigma sulit untuk mengelak bahwa citra diri mereka ataupun kelompok mereka dipandang negatif dari orang lain, dan hal ini akan membentuk self esteem yang rendah pula.

Coopersmith

mendefinisikan self esteem sebagai suatu evaluasi diri apakah seseorang merasa mampu, berharga dan berhasil dan penting. Faktor-faktor yang mempengaruhi tinggi rendahnya self esteem seseorang adalah penghargaan dan penerimaan dari significant others, nilainilai yang dimiliki oleh seseorang dan bagaimana cara seseorang dalam menanggapi devaluasi yang terjadi padanya. Berdasarkan hal ini, salah satu faktor self esteem yang berkaitan dengan experienced stigma adalah cara seseorang dalam menanggapi devaluasi. Devaluasi yang dimaksud disini berupa evaluasi negatif dari orang lain. Seseorang yang mampu menanggapi evaluasi tersebut dengan baik, cenderung memiliki self esteem yang tinggi, begitu juga dengan sebaliknya, apabila seseorang menanggapi evaluasi negatif dengan tidak baik, maka akan membentuk self esteem yang rendah.

Berdasarkan data wawancara yang telah dilakukan, suku Nias menyadari kalau mereka dinilai secara negatif oleh orang lain, seperti orang bersuku Nias jahat, mempunyai ilmu hitam, dan lain sebagainya. Namun, meskipun menyadari hal tersebut, mereka tidak menginternalisasi penilaian yang muncul kepada dirinya sendiri. Sementara itu, seperti yang sudah dijelaskan sebelumnya, perceived stigma merupakan perasaan negatif yang terbentuk akibat dari internalisasi stigma yang diterima dan persepsi individu tersebut terhadap perilaku orang lain kepadanya sebagai orang yang terkena stigma. Dalam hal ini, Mickelson dan William (2008) membaginya kedalam dua dimensi, yaitu internalized stigma (perasaan negatif yang muncul karena internalisasi stigma) dan experienced stigma (persepsi individu tersebut terhadap perilaku orang lain kepadanya).

Jika dilihat dari pengalaman dan respon suku Nias terhadap stigma yang ada pada mereka dan merujuk kepada pengertian perceived stigma seperti yang dijelaskan sebelumnya, peneliti merasa bahwa stigma yang dirasakan suku Nias ini lebih mengarah kepada experienced stigma, yaitu persepsi atau keyakinan tersendiri mengenai bagaimana perasaan orang lain terhadap dirinya sebagai kelompok yang terkena stigma, dalam hal ini sebagai orang yang bersuku Nias. Mickelson (2008) juga mengungkapkan bahwa experienced stigma berhubungan secara tidak langsung dengan penurunan self esteem. Sehingga, peneliti memilih untuk melihat bagaimana 
peran experienced stigma terhadap self esteem pada suku Nias.

\section{KERANGKA TEORITIS}

\section{Self- Esteem}

Menurut Larsen dan Buss (2008), harga diri (self esteem) merupakan apa yang kita rasakan berdasarkan pengalaman yang kita peroleh selama menjalani hidup. Coopersmith (1967) mendefinisikan self-esteem sebagai sejauh mana individu mempercayai bahwa dirinya mampu, penting, berhasil, dan berharga. Definisi ini lebih menekankan kepada evaluasi yang dilakukan oleh individu sendiri yang mencakup sejumlah penilaian terhadap diri sendiri berdasarkan kriteria tertentu. Selanjutnya Branden (1981) menekankan self-esteem sebagai apa yang dipikirkan dan dirasakan oleh individu tentang diri mereka sendiri, bukan mengenai apa yang dipikirkan dan dirasakan oleh orang lain tentang diri kita.

Robson (1988) mengatakan bahwa orang yang memiliki self-esteem yang tinggi ditandai dengan kepercayaan diri yang tinggi, rasa puas, memiliki tujuan yang jelas, selalu berpikir positif, mampu untuk berinteraksi sosial, solving problem yang tinggi, serta mampu menghargai diri sendiri, sedangkan orang yang memiliki self-esteem yang rendah ditandai dengan rasa takut, cemas, depresi, dan tidak percaya diri.

Menurut Coopersmith dimensi self esteem terdiri dari:

\section{Feeling of Belonging}

Perasaan individu sebagai bagian dari kelompok dan merasa dirinya diterima, diinginkan, serta diperhatikan oleh kelompoknya. Kelompok ini dapat berupa keluarga, kelompok teman sebaya, dan sebagainya.

2. Feeling of Competence

Perasaan individu bahwa dirinya yakin pada hasil pekerjaan dan kemampuannya dalam mencapai hasil yang diharapkan serta dalam menghadapi permasalahan. Individu yang memiliki perasaan mampu umumnya memiliki nilai-nilai dan sikap yang demokratis serta orientasi yang realistis.

3. Feeling of Worth

Perasaan individu dimana dia merasa dirinya berharga. Perasaan ini banyak dipengaruhi oleh pengalaman masa lalu. Perasaan yang dimiliki individu sering ditampilkan dan berasal dari pernyataan-pernyataan positif yang sifatnya pribadi seperti pintar, sopan, baik dan lain-lain. Individu yang merasa dirinya berharga cenderung dapat mengontrol tindakan-tindakannya terhadap dunia di luar dirinya

\section{Experienced Stigma}

Experienced stigma adalah salah satu dimensi yang membentuk perceived stigma (Mickelson, 2008). Menurut Mickelson, experienced stigma adalah persepsi seseorang terhadap pengalaman stigma yang diterimanya dari orang lain. Stigma ini lebih mengarah kepada bagaimana seseorang yang terkena stigma mempersepsikan perilaku orang di sekitarnya terhadap dirinya sebagai orang yang terkena stigma. Biasanya stigma ini berhubungan dengan pengalamn-pengalaman terkait dengan diskriminasi maupun prejudice. Beberapa peneliti juga memiliki istilah yang berbeda- beda dalam 
menggambarkan experienced stigma ini, seperti enacted stigma dan public stigma.

Goffman (1963) mengatakan enacted stigma merupakan perilaku nyata (seperti pengucilan atau diskriminasi sosial secara langsung) oleh orang lain untuk mendiskreditkan atau mengabaikan seseorang yang memiliki kondisi tertentu. Jacoby (1994); Scrambler (2004), mengatakan bahwa enacted stigma merupakan perilaku atau persepsi orang lain terhadap individu yang dianggap memiliki atribut yang berbeda. Selanjutnya, Donaldson (2015) mengatakan bahwa public stigma merupakan sikap negatif yang ditunjukkan oleh orang lain terhadap individu yang terkena stigma. Horch (2011) juga mengatakan bahwa enacted stigma terjadi ketika individu mengalami kesulitan sebagai akibat dari label yang diterimanya dari orang lain. Label yang diberikan ini bisa berupa hubungan kondisi stigma dengan stereotype yang ada di kelompok (Link dan Phelan, 2001).

\section{Suku Nias}

Suku Nias adalah suku bangsa atau kelompok masyarakat yang sebagian besar mendiami pulau Nias, Provinsi Sumatera Utara. Suku ini memiliki nilai-nilai budaya yang dipegang sebagai falsafah hidupnya. Menurut Tuhoni Telaumbanua (2010) Nilai-Nilai budaya yang dianut oleh suku Nias antara lain :

\section{Banua dan Fatalifusöta}

Fatalifusöta memiliki makna "persaudaraan" yang tidak hanya berdasarkan atas hubungan darah (sesama marga atau suku), tetapi juga hubungan persaudaraan karena berada dalam satu lingkungan (satu bапиa) meskipun suku, agama atau kepercayaan berbeda.

2. Emali dome si so bal ala, ono luo na so yomo

Ungkapan ini merupakan salah satu falsafah hidup suku Nias. Ungkapan tersebut jika diterjemahkan dalam bahasa Indonesia adalah sebagai berikut : " Seseorang yang masih berada di jalan di anggap sebagai tamu tak dikenal atau orang asing, namun jika seseorang itu dapat menjadi saudara yang sangat dihormati kalau ia sudah berada di dalam rumah kita”. Ungkapan ini sebenarnya suatu bentuk penghormatan kepada orang asing (pendatang). Intinya adalah ketika seseorang sudah dianggap menjadi bagian dari masyarakat Nias, maka orang tersebut tidak dianggap sebagai orang asing lagi, melainkan sebagai saudara yang sama dengan saudara-saudara lainnya dalam wilayah atau banua.

3. Sebua ta'ide'ide'ö, side'ide'ide mutayaigö

Ungkapan ini sering digunakan dalam menyelesaikan konflik atau masalah yang terjadi di kalangan masyarakat Nias. Ungkapan ini mengandung makna yang berarti bahwa masalah yang terjadi jangan dibesar-besarkan, sebaliknya diusaha-kan untuk menjadi lebih kecil lagi sehingga dapat di selesaikan secara tuntas tanpa meninggalkan bekas atau dendam apapun di hati kedua belah pihak yang bermasalah. 


\section{HIPOTESIS PENELITIAN}

Hipotesa dalam penelitian ini adalah: "Ada peran experienced stigma terhadap self esteem". Semakin tinggi experienced stigma, maka self esteem semakin rendah.

\section{METODE}

Jenis penelitian yang digunakan dalam penelitian ini adalah penelitian kuantitatif korelasional, yang bertujuan untuk melihat hubungan antar variable.

\section{Variabel Penelitian}

Variabel kriteria yang digunakan dalam penelitian ini adalah Experienced Stigma dan variabel prediktor dalam penelitian ini adalah Self Esteem.

\section{Partisipan}

Teknik pengambilan participan yang digunakan adalah teknik insidental dengan jumlah partisipan dalam penelitian ini adalah 151 orang yang memenuhi karakteristik:

1. Bersuku Nias

2. Berusia diatas 20 tahun

\section{Alat Ukur}

$$
\text { Pada penelitian ini, }
$$
pengumpulan data dilakukan dengan menggunakan skala. Terdapat 2 (dua) skala yang digunakan yaitu skala experience stigma dan skala selfesteem. Penskalaan yang digunakan dalam penelitian ini adalah penskalaan Likert, yang diuraikan ke dalam bentuk pernyataan favourable dan unfavourable. Pernyataan favour-able merupakan pernyataan yang mendukung atribut yang diukur, sedangkan pernyataan unfavourable merupakan pernyataan tidak mendukung atribut yang diukur (Azwar, 2010). Setiap aitem terdiri 5 alternatif jawaban, yaitu: Sangat Sesuai (SS), Sesuai (S), Netral (N), Tidak Sesuai (TS), dan Sangat Tidak Sesuai (STS). Nilai dari setiap pilihan akan bergerak dari angka 1 sampai dengan 5 .

\section{Uji Realibilitas dan Uji Daya Diskriminasi Aitem}

1. Skala 1 - Experienced Stigma

Jumlah aitem experienced stigma yang diuji cobakan adalah sebanyak 20 aitem. Dari hasil uji coba tersebut terdapat 1 aitem yang gugur karena memiliki daya diskriminasi aitem dibawah 0,3. Hasil uji coba skala ini memiliki koefisien $\alpha=$ 0,879 dengan daya diskriminasi aitem yang bergerak dari 0,312 sampai 0,731.

2. Skala 2 -Self-Esteem

Jumlah aitem self esteem yang diuji cobakan adalah sebanyak 44 aitem. Dari hasil uji coba tersebut terdapat 12 aitem yang gugur karena memiliki daya diskriminasi aitem dibawah 0,3. Hasil uji coba skala ini memiliki koefisien $\alpha=0,912$ dengan daya diskriminasi aitem yang bergerak dari 0,344 sampai 0,705 .

\section{Teknik Analisa Data}

Data dalam penelitian ini akan dianalisa dengan analisa statistik, yang dapat bekerja dengan angka-angka, bersifat objektif dan universal (Hadi, 2002). Analisa data yang digunakan dalam penelitian ini adalah uji statistik regresi sederhana untuk melihat hubungan antara variable bebas (Experienced stigma) dengan variable tergantung (self-esteem) pada Suku Nias. 
Uji Normalitas

Uji normalitas sebaran menggunakan analisis statistik Kolmogorov-Smirnov. Data dikatakan terdistribusi normal jika harga $\mathrm{p}>0.05$. Hasil uji normalitas dengan menggunakan One Sample Kolmogorov-Smirnov Test adalah sebagai berikut :

Tabel 1. Uji Normalitas

\begin{tabular}{cc}
\hline Variabel & $\mathbf{P}$ \\
\hline Experienced Stigma & 0,178 \\
Self Esteem & 0,642 \\
\hline
\end{tabular}

Berdasarkan tabel diatas, diperoleh bahwa nilai p pada variabel experienced stigma adalah sebesar 0,178 yang berarti bahwa data terdistribusi secara normal. Nilai p pada self esteem sebesar 0,642 menunjukkan bahwa data terdistribusi secara normal.

\section{Uji Linearitas}

Uji linearitas bertujuan untuk mengatetahui apakah korelasi antara variabel independen dan variabel dependen membentuk garis linear atau tidak. Uji linearitas dalam penelitian ini menggunakan metode statistik uji F. Data penelitian berkorelasi secara linear apabila nilai $\mathrm{p}$ untuk linearity < 0,05. Hasil uji linearitas dapat dilihat pada tabel berikut.

Tabel 2. Uji Linearitas

\begin{tabular}{ccc}
\hline Variabel & Linearity & $\begin{array}{c}\text { Deviation } \\
\text { from } \\
\text { Linearity }\end{array}$ \\
\hline $\begin{array}{c}\text { Peran Experience } \\
\text { Stigma terhadap } \\
\text { Self Esteem }\end{array}$ & 0.000 & 0.017 \\
\hline
\end{tabular}

HASIL

Tabel 3. Hasil Analisis Regresi Linear Sederhana

\begin{tabular}{lllll}
\hline Model Koef. Korelasi & $\begin{array}{c}\text { Koef. } \\
(\mathbf{R})\end{array}$ & $\begin{array}{c}\text { Determinan } \\
\left(\mathbf{R}^{2}\right)\end{array}$ & $\mathbf{P}$ & $\mathbf{F}$ \\
\hline 1 & 0,540 & 0,2 & 0,000 & 61,373 \\
\hline
\end{tabular}

Berdasarkan tabel di atas, diperoleh nilai $F$ sebesar 61,373 dan nilai $\mathrm{p}<0,05$, yaitu sebesar 0,000 . Hal ini menunjukkan bahwa experienced stigma mampu memprediksi self esteem pada suku Nias. Dengan demikian, hipotesis utama dalam penelitian ini diterima, yaitu ada peran experienced stigma terhadap self esteem pada suku Nias. Selanjutnya, besar korelasi variabel experienced stigma terhadap self esteem pada suku Nias adalah 0,540. Hasil analisis regresi juga menunjukkan bahwa nilai koefisien determinan $\left(\mathrm{R}^{2}\right)$ sebesar 0,292 atau 29,2\%. Dengan kata lain, variable experienced stigma memberikan pengaruh sebesar 29,2\% terhadap self esteem suku Nias. Sedangkan sisanya $70,8 \%$ dipengaruhi oleh faktor lain yang tidak diteliti dalam penelitian ini.

Selanjutnya hasil analisis koefisien regresi adalah sebagai berikut.

Tabel 3. Hasil Analisis Koefisien Regresi

\begin{tabular}{cc}
\hline Model & Koefisien Regresi \\
\hline Konstan & 151,782 \\
Experienced Stigma & $-0,946$
\end{tabular}

Persamaan garis linear sederhana adalah $\mathrm{Y}=\mathrm{a}+\mathrm{bX}$ dengan $\mathrm{Y}$ melambangkan self esteem suku Nias, $\mathrm{X}$ melambangkan experienced stigma, a merupakan harga konstan ketika $X=0$, dan $b$ merupakan koefisien regresi yang 
menunjukkan peningkatan ataupun penurunan variabel dependen yang didasarkan pada perubahan variabel independen.

Berdasarkan tabel 3, persamaan garis linear sederhana dalam penelitian ini adalah $\mathrm{Y}=151,782-$ 0,946X. Persamaan ini menunjukkan bahwa jika tidak ada experienced stigma, telah terbentuk self esteem sebesar 151,782. Koefisien regresi -0,946 menunjukkan bahwa setiap penambahan 1 satuan experienced stigma akan menurunkan self esteem suku Nias sebesar 0,946.

Kategorisasi data variable experienced stigma diperoleh bahwa sebagian besar experienced stigma pada subjek penelitian ini berada pada kategori positif yaitu sebanyak 121 orang $(80,1 \%)$. Hal ini menunjukkan bahwa ai kelompok yang terkena stigma.80,1\% suku Nias yang menjadi subjek penelitian ini tidak membentuk perasaan atau keyakinan yang negatif terhadap pandangan orang lain kepada dirinya sebagai kelompok yang terkena stigma.

Kategorisasi data variable selfesteem didapatkan bahwa sebagian besar self esteem subjek penelitian ini berada pada kategori tinggi, yaitu sebanyak $58,9 \%$. 40,4 \% subjek penelitian berada dalam kategori sedang dan $0,7 \%$ berada dalam kategori rendah. Dari hasil di dapatkan bahwa sebagian besar suku Nias yang menjadi subjek penelitian ini memiliki self esteem yang tinggi, artinya mereka membentuk evaluasi dirinya sendiri secara positif.

\section{DISKUSI}

Berdasarkan hasil penelitian ini diketahui bahwa ada hubungan negatif antara perceived stigma terhadap self- esteem pada orang bersuku Nias yang artinya adalah semakin tinggi nilai perceived stigma yang dirasakan oleh seseorang, maka akan berdampak pada penurunan self esteem, begitu juga dengan sebaliknya. Selanjutnya, pada penelitian ini, experienced stigma suku Nias yang menjadi subjek penelitian berada dalam kategori positif. Sehingga dapat dikatakan bahwa mereka tidak mempersepsikan evaluasi-evaluasi negatif dari orang lain sebagai suatu stigma dan hal ini tidak menyebabkan penurunan self esteem.

Hasil analisa tersebut didukung oleh pendapat Camp, Finley dan Lyons (2002); Watson dan River (2005) (dalam Mickelson, 2008) yang mengatakan bahwa penurunan self-esteem tidak selalu terjadi kepada individu yang berada dalam kelompok yang terkena stigma, karena tidak semua individu tersebut menerima societal labels atau stereotype yang dibentuk oleh masyarakat.

Hal-hal yang mempengaruhi tidak menurunnya self esteem pada suku Nias di penelitian ini, masih belum diketahui. Akan tetapi, peneliti berasumsi bahwa hal ini bisa ditinjau dari cara seseorang mempersepsikan sesuatu, termasuk evaluasi dari orang lain. Menurut Robins (1998), ada beberapa faktor yang mempengaruhi persepsi seseorang, salah satunya ialah perceiver atau karakter yang ada pada individu, termasuk latar belakang budaya yang dimiliki oleh individu tersebut.

Afthonul (2010) mengatakan bahwa tradisi yang ada pada suku Nias terwarisi secara lintas generasi berdampak pada pembentukan kepribadian orang Nias saat ini. Menurut Faoziduhu (2012), ada satu falsafah suku Nias yang menggambarkan bahwa harga diri yang tinggi merupakan hal yang paling penting 
dalam masyarakat suku Nias, yaitu Sokhi Mate Moroi Aila, yang artinya secara harafiah adalah lebih baik mati daripada malu. Nilai ini hampir diterapkan ke seluruh aspek kehidupan suku Nias. Hal ini tampak jelas pada adat-istiadat yang berlaku pada suku Nias, seperti jujuran (mahar) yang terbilang cukup tinggi, adanya tingkatan dalam struktur sosial masyarakat, atau tradisi owasa (tradisi pesta tiga hari tiga malam dengan mengorbankan puluhan bahkan ratusan babi).

Faoziduhu (2012) juga mengatakan bahwa meskipun kebiasaan-kebiasan tersebut, (seperti mengadakan Owasa), lambat laun mulai ditinggalkan karena perkembangan zaman, tetapi dalam kehidupan pergaulan sosial prinsip "tidak ingin dipermalukan" tetap terlihat. Misalnya bila seseorang bertamu di suatu keluarga, maka keluarga tersebut meskipun tidak mampu secara ekonomi akan mencoba dengan segala daya upaya mengadakan pesta kecil untuk menyambut tamunya yang dihormati. Dari hal ini didapatkan bahwa dari segi budaya pun suku Nias sudah memiliki harga diri (self esteem) yang tinggi.

\section{KESIMPULAN}

Berdasarkan hasil penelitian yang diperoleh, maka ditarik kesimpulan sebagai berikut:

1. Experienced Stigma memiliki hubungan yang negatif terhadap self esteem. Setiap penambahan nilai experienced stigma akan menurunkan self esteem.

2. Sumbangan efektif yang diberikan variabel experienced stigma terhadap self esteem orang bersuku
Nias adalah sebesar 29,2\%, yang berarti bahwa perceived stigma mempengaruhi self esteem sebesar $29,2 \%$, sedangkan sisanya dipengaruhi oleh faktor lain.

3. Hampir seluruh orang bersuku Nias yang menjadi subjek penelitian ini memiliki experienced stigma berada dalam kategori positif, yang artinya orang bersuku Nias tidak membentuk persepsi yang negatif mengenai perilaku orang lain terhadap dirinya sebagai seorang suku Nias.

4. Sebagian besar Self Esteem subjek penelitian berada dalam kategori tinggi, artinya evaluasi orang bersuku Nias terhadap dirinya sendiri positif.

5. Berdasarkan hasil analisis data, maka dapat disimpulkan bahwa suku Nias yang menjadi subjek penelitian ini tidak mempersepsikan evaluasievaluasi negatif dari orang lain sebagai suatu stigma, sehingga hal ini tidak menyebabkan penurunan self esteem mereka.

\section{SARAN}

\section{Saran Metodologis}

Peran experienced stigma terhadap self esteem sebesar 29,2\%, dan selebihnya $70,8 \%$ dipengaruhi oleh variabel lain yang tidak diteliti dalam penelitian ini. Sehubungan dengan hal tersebut, maka disarankan kepada peneliti selanjutnya yang berminat meneliti variabel experienced stigma untuk mengkaji faktorfaktor lain yang turut mempengaruhi variabel tersebut, seperti faktor budaya, atau faktor-faktor yang mempengaruhi cara seseorang dalam mempersepsikan stigma atau penilaian dari orang lain. 


\section{Saran Praktis}

Berdasarkan hasil yang telah diperoleh, penelitian ini memberikan informasi bahwa orang bersuku Nias merasa bahwa mereka terkena stigma dari orang lain. Akan tetapi hal tersebut tidak menurunkan self esteem.

\section{REFERENSI}

Sarwono, Sarlito (2009). Psikologi Sosial. Jakarta: Balai Pustaka

Hogg, Michael A.,dkk. (2011). Social Psychology Third Edition. New York: Prentice Hall.

Link, B. G., Struening, E. L., Rahav, M., Phelan, J. C., \& Nuttbrock, L. (1997). On stigma and its consequences: Evidence from a longitudinal study of substance abuse. Journal of Health and Social Behavior, 38, 177-190.

Mickelson, Kristin., \& Stacey, W. (2008). Perceived Stigma of Poverty and Depression: Examination of Interpersonal and Intrapersonal Mediators. Journal of Social and Clinical Psychology. (pp. 903-930). East Tennesse State University

Coopersmith, Stanley. (1967). The Antecedents of Self Esteem. San Fransisco: W. H. Freeman.

Larsen, R.J. \& Buss, D.M. (2005). Personality psychology: domains of knowledge about human nature. Boston: McGraw-Hill.

Branden, N. (1981). The psychology of self esteem: A new concept. Toronto: Bantam Books.

Robson, P.J. (1988). Self-esteem- psychiatric view. British Journal

of Psychiatry. www.bjp.rcpsych.org/ Diakses 4 September 2016. 